\title{
3. Painful Bladder Syndromes
}

\author{
아주의대 \\ 김 영 수
}

통증성 방광증후군 또는 방광통증후군은 세 균의 감염이나 뚜렷한 병리학적인 원인 없이 방광과 그 주변에 통증을 야기하는 것으로서 대부분 빈뇨와 요급을 동반한다. 이러한 방광통 의 원인은 1) 여성요도증후군 (Urethral Syndrome), 2) Sensory Urgency, 3) 간질성 방광염 (Interstitial Cystitis) 의 세가지로 나눌 수 있으 나 모두 다 병인이나 정의가 불분명하고 확립 되어 있지 않아 최근에는 모두 한데 묶어 Painful bladder syndromes 으로 통칭하는 추세 이다.

방광통증후군의 가장 주가 되고 대표적인 간 질성방광염은 주로 $30 \sim 50$ 대의 백인 여성에 호발하는 질환으로 알려져 있으나 실제로는 국 내에서도 이 질환에 대한 관심이 고조되면서 최근에 많이 발견되고 있다.

간질성방광염의 진단은 증상과 마취하에서 방광내벽의 특징적인 Petechial hemorrhage (glomerulation)가 가장 지표가 되며 별표에서와 같은 많은 조건들의 exclusion을 요하는 "exclusive diagnosis"라 할 수 있다.

간질성 방광염의 원인적 가설로는 1) Infection 2) Mast cell involvement 3) Epithelial Permeability 4) Neurogenic mechanism 5) Hypoxia 6) Autoimmunity 등의 많은 원인이 있으나 자가 면역기전에 의한 방광상피의 투과성 증가로 인 해 요의 독성물질이 방광근육층으로 들어가 염 증반응을 일으키며 histamine의 분비가 결국 방 광의 통증을 유발한다는 것이 최근의 사조이다.

치료는 일차적으로 수압을 이용한 "Hydrodis- tention of the bladder"가 있으며 내과적 요법으 로는 Amitriptyline (tricyclic antidepressant), 항 히스타민제, Elmiron (Pentosan Polysulfate) 등 이 있으며 Intravesical therapy 로는 DMSO (Rimso - 50), Clorpactin, Heparine 등이 있다.

NIADDK RESEARCH DEFINATION OF INTERSTITIAL CYSTITIS

\section{Required Criteria :}

Glomerulations or Hunner's ulcer on cystoscopic examination and Pain associated with the bladder or urinary urgency

Examination for glomerulations should occur after distension of bladder under anesthesia to 80-100 cm H2O for 1-2 min. Bladder may be distended up to two times before evaluation.

Glomerulations must be diffuse-present in at least three quadrants of the bladder-and there must be at least 10 glomerulations per quadrant.

Glomerulations must not be along path of cystoscope (to eliminate artifact from contact instrumentation). Presence of any one of the following criteria excludes diagnosis of interstitial cystitis :

1. Bladder capacity of greater than $350 \mathrm{ml}$ on awake cystometry using either gas or liquid as filling medium 
2. Absence of intense urge to void with bladder filled to $100 \mathrm{ml}$ of gas or $150 \mathrm{ml}$ of water during cystometry, using a fill rate of $30-100 \mathrm{ml} / \mathrm{min}$

3. Demonstration of phasic involuntary bladder contractions on cystometry using fill rate described above

4. Duration of symptoms less than 9 months

5. Absence of nocturia

6. Symptoms relived by antimicrobials, urinary antiseptics, anticholinergics, or antispasmodics (musculotropic relaxants)

7. Frequency of urination, while awake, of fewer than eight times per day
8. Diagnosis of bacterial cystitis or prostatitis within 3-month period

9. Bladder or lower ureteral calculi

10. Active genital herpes

11. Uterine, cervical, vaginal, or urethral cancer

12. Urerhral diverticulum

13. Cylophosphamide or any type of chemical cystitis

14. Tuberculous cystitis

15. Radiation cystitis

16. Benign or malignant bladder tumors

17. Vagintis

18. Age less than 18 years

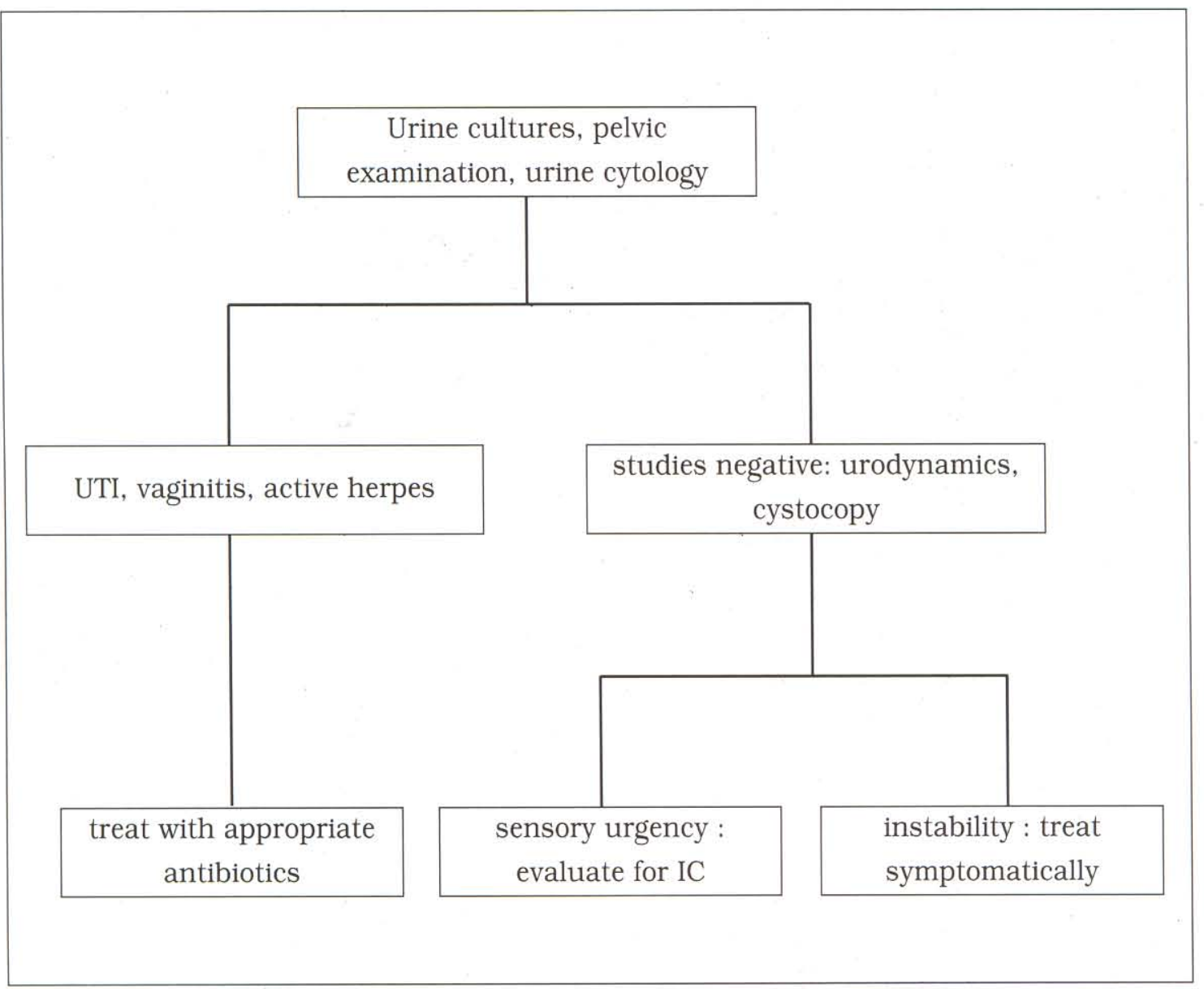




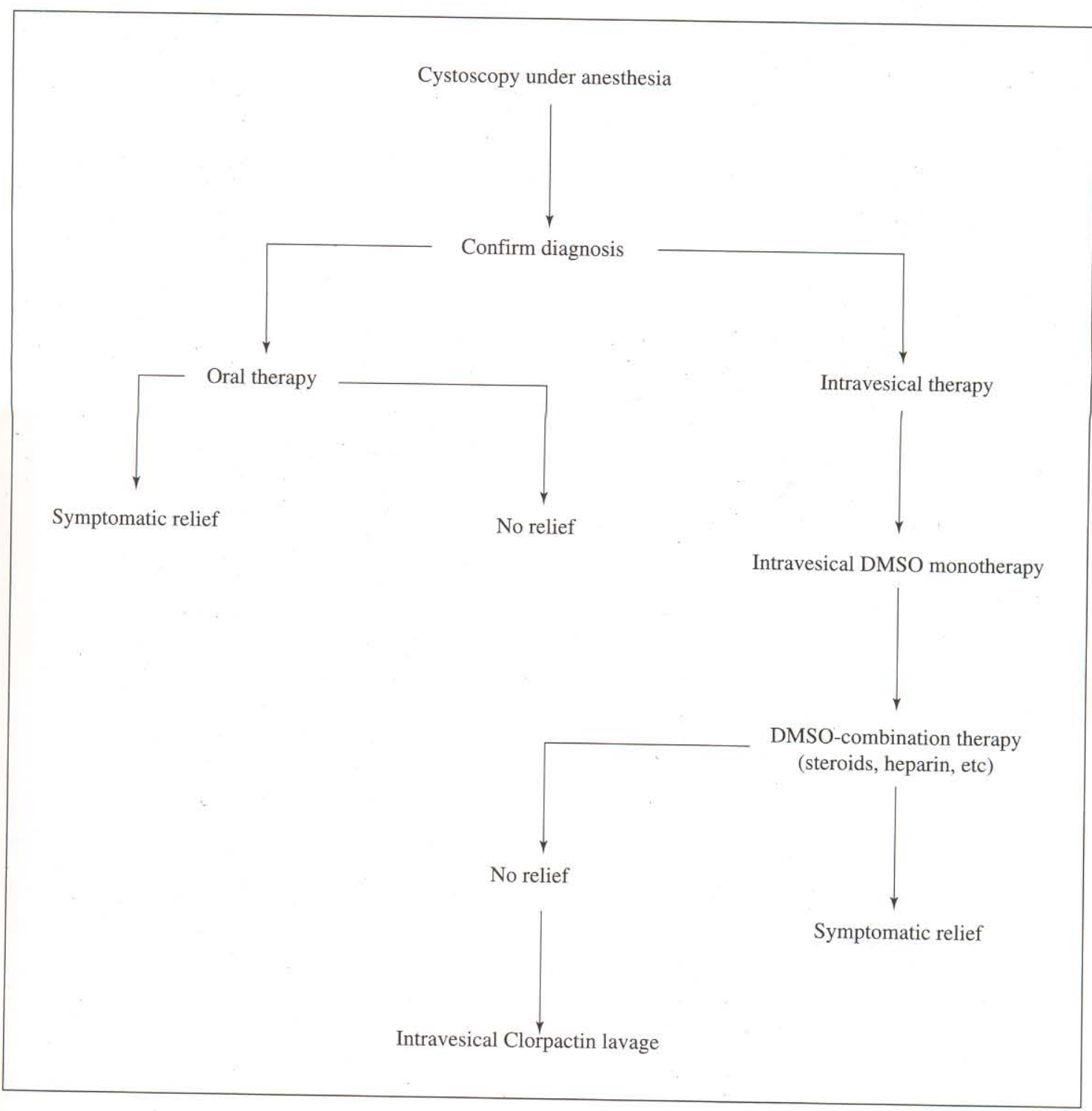

Suggested treatment algorithm for interstitial cystitis 